\title{
POLLEN SEASONS OF SELECTED TREE AND SHRUB TAXA IN KRAKÓW AND ITS NEIGHBOURHOOD
}

\author{
Dorota Myszkowska ${ }^{1}$, Bartosz Jenner ${ }^{2}$, Katarzyna Cywa ${ }^{3}$, Monika Kuropatwa ${ }^{4}$, \\ Danuta Stępalska ${ }^{4}$, Katarzyna Piotrowicz ${ }^{5}$
}

\author{
${ }^{1}$ Department of Clinical and Environmental Allergology, Medical College, Jagiellonian University, Śniadeckich 10, 31-531 Kraków, \\ ${ }^{2}$ Department of Clinical and Environmental Toxicology, Medical College, Jagiellonian University, Złotej Jesieni 1, 31-826 Kraków, \\ ${ }^{3}$ Institute of Botany Polish Academy of Sciences, Lubicz 46, 31-512 Kraków, \\ ${ }^{4}$ Institute of Botany, Jagiellonian University, Kopernika 27, 31-531 Kraków, \\ ${ }^{5}$ Department of Climatology, Jagiellonian University, Gronostajowa 7, 30-387 Kraków, Poland \\ e-mail:dmyszkow@cm-uj krakow.pl
}

Received: 24.09.2007

\section{S u m m a r y}

The aim of the study was to compare the dynamics of pollen seasons of selected tree and shrub taxa among measurement sites in Kraków and its neighbourhood. The study was performed in Kraków and Piotrkowice Małe in 2002, as well as in Kraków and Giebułtów in 2006. During the study the volumetric method was applied and pollen grains were counted along four horizontal lines.

The lowest percentage of Corylus pollen and the highest percentage of Betula pollen were found in the analysed sites. The differences among start dates in various measurement sites in a given year were inconsiderable. Statistically significant differences of SPI values for the majority of taxa were found between measurement sites and between seasons for Kraków.

The pollen season dynamics showed one (Betula, Pinaceae) or more maximum values (Corylus, Populus, Fraxinus, Salix). The occurrence of many peaks could be explained by the appearance of several species within one genus in the studied area or by various weather conditions. In 2002 maximum pollen concentrations were recorded earlier than in 2006. The differences in these dates could be explained better by cumulative temperature $>5^{\circ} \mathrm{C}$ than $>0^{\circ} \mathrm{C}$.

Key words: Tree pollen, pollen season, Seasonal Pollen Index, urban and suburban area, cumulative temperature

\section{INTRODUCTION}

Information about pollen concentration measurements in urban and suburban areas performed in short time series are known in literature (G o t t a r d in i and Crist o fol in i, 1997; K a sprzyk, 1999). The results of these studies indicate disparities in annual pollen concentrations in various sites, and slight differences in the course of pollen seasons (start dates, duration).
Meteorological parameters, especially specific characteristics of urban climate and vegetative cover, influence the pollen season (F u ku ok a, 1997). Changes in vegetative cover in big cities result from human activity.

The aim of the study was to compare the dynamics of pollen seasons of selected tree and shrub taxa among measurement sites in Kraków and two sites in its neighbourhood. The study was performed in Kraków and Piotrkowice Małe in 2002, as well as in Kraków and Giebułtów in 2006.

\section{MATERIALS AND METHODS}

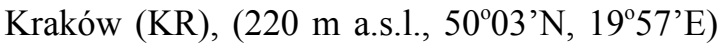
is located in the Małopolska province. Forests in Kraków occupy $4.23 \%$ of its area. Fagus (20.5\%), Quercus (19.0\%), Pinus (about 15.0\%), Betula (14.0\%), Alnus (10.1\%), Fraxinus $(2.7 \%)$ and Carpinus $(4.9 \%)$ dominate (Turzański and Pa u la - Wilga, 2002).

Piotrkowice Małe (PM) $\left(50^{\circ} 12^{\prime} \mathrm{N}, 20^{\circ} 14^{\prime} \mathrm{E}\right)$ a small village, is located about $40 \mathrm{~km}$ north of Kraków. Forests occupy about $2 \%$ of its area. Mixed forests, subcontinental forests growing on dry ground, pine-oak forests and communities of elm-ash and willow-poplar marshy meadows dominate in this area (Tow pas z et al. 1998).

Giebultów (GB), $\left(50^{\circ} 08^{\prime} \mathrm{N}, 19^{\circ} 53^{\prime} \mathrm{E}\right)$ is located about $14 \mathrm{~km}$ north west of Kraków. Poplar, willow, alder and hazel prevail. There is a low contribution of pine and beech (Tow pa s z, 1996).

In Kraków a heat island occurs (air temperature increased by $1-2^{\circ} \mathrm{C}$ ) which is responsible for change of the thermal season duration in the year. In the center of the city, summer lasts longer by 25 days and winter 
lasts shorter by 23 days than in suburban area. In Kraków the number of hot days is higher by 10-11 days and also accumulated rainfall is higher than in suburban area (L e wińs k a , 2000). Mean temperature for January 2002 was $-0.5^{\circ} \mathrm{C}$, although in the second half of this month temperature increased up to over $10^{\circ} \mathrm{C}$. February 2002 was the warmest since 1991 (mean temperature was $4.3^{\circ} \mathrm{C}$ ). The beginning of 2006 was one of the coolest since 1991 (mean temperature for January was $-7.0^{\circ} \mathrm{C}$, for February $-2.2^{\circ} \mathrm{C}$, for March $1.0^{\circ} \mathrm{C}$ ) and snow cover was long lasting up to the $22^{\text {nd }}$ of March (communication of the Department of Climatology, Jagiellonian University).

The study was performed using the volumetric method. In Kraków and Giebułtów the traps were installed at a height of $20 \mathrm{~m}$ and in Piotrkowice Małe at a height of $15 \mathrm{~m}$ above ground level. The duration of the study in Kraków was from the $15^{\text {th }}$ of January to the $2^{\text {nd }}$ of December in 2002 and from the $1^{\text {st }}$ of March to the $31^{\text {st }}$ of December in 2006; in Piotrkowice Małe from the $6^{\text {th }}$ of February to the $11^{\text {th }}$ of November in 2002 and in Giebultow from the $8^{\text {th }}$ of March to the $15^{\text {th }}$ of August in 2006.

Average daily pollen concentrations $\left(\mathrm{pg}^{-3}\right)$ were obtained by counting pollen grains along four horizontal lines at $400 \times$ magnification of a light microscope. Eight selected tree and shrub taxa were analysed: Alnus, Corylus, Betula, Populus, Fraxinus, Quercus, Salix, Pinaceae (Pinus, Picea). To calculate pollen seasons, the 95\% method was applied.

The saw like scatter plot of data describing day to day variation in pollen concentrations were smoothed by means of Generalized Additive Model ( $\mathrm{H}$ a s t i e et al. 2001). In this modelling we assumed that the number of pollen grains collected in successive days undergoes the Poisson distribution. The pair wise comparison of SPI values calculated for given sites and pollen seasons was done using a version of the Student $t$-test adopted for counts (S o k a l and R h a lf, 1998).

\section{RESULTS}

Table 1 presents the taxa pollen percentage in annual sums of tree pollen, and table 2 shows pollen season parameters. The differences among start dates of various measurement sites in a given year were inconsiderable and amounted to several days except at Fraxinus (12 days) and Quercus (33 days). In 2002 the pollen seasons of all the studied taxa started earlier than in 2006. The highest differences in start dates between particular years were found for Alnus (55 days) and Corylus (53 days).

In the studied sites and years, clearly significant differences in SPI values were recorded, except at KR vs PM in 2002 for Corylus and Pinaceae (borderline significant; $\mathrm{p}=0.0496$ ) and at KR02 vs KR06 for Salix $(\mathrm{p}=0.9569)$. In 2002 SPI values were significantly higher in Kraków for Betula, Fraxinus, Quercus and Salix, and in 2006 for Quercus, Corylus, Salix, Alnus and Pinaceae (Fig. 2, Tab. 2).

Figure 3 presents the dynamics of particular taxa pollen seasons. For Betula, Quercus and Pinaceae, one pollen peak concentration was observed. In case of $\mathrm{Co}$ rylus, Populus, Fraxinus, Salix, more than one peak concentrations were noted. Generally speaking, the highest pollen concentrations were observed earlier in 2002 than in 2006. The delay in 2006 was smaller when it referred to the taxa whose pollen occurred later in the course of the season (Fig. 4).

Different dates of the highest pollen concentrations in 2002 and 2006 could be explained in a qualitative way by using cumulative temperature $>0^{\circ} \mathrm{C}$ and $>5^{\circ} \mathrm{C}$ (Fig. 5). Cumulative temperature (from the $1^{\text {st }}$ of January to the $30^{\text {th }}$ of March 2006 ) of $5^{\circ} \mathrm{C}$ and over $5^{\circ} \mathrm{C}$ was $290^{\circ} \mathrm{C}$ on the $90^{\text {th }}$ day of a year. The same temperature in 2002 was noted on the $75^{\text {th }}$ day of a year. The ninetieth day in 2006 was also the day of the peak concentration of Corylus pollen. In 2002 the first Corylus pollen peak concentration was almost two months earlier. Even though the second peak occurrence is taken into consideration, the difference between the studied years was about 25 days. Figure 5 shows that the differences between cumulative temperature curves disappear as the season proceeds. The delay of the season on the $130^{\text {th }}$ day in 2006 was 8 days in comparison with 2002. The same delay occurred for the flowering of the latest taxa (Quercus, Pinaceae).

Table 1

Pollen percentage of particular tree and shrub taxa in annual totals.

\begin{tabular}{|l|c|r|r|r|}
\hline \multirow{2}{*}{ Taxon } & \multicolumn{2}{|c|}{2002} & \multicolumn{2}{c|}{2006} \\
\cline { 2 - 5 } & KR & PM & KR & GB \\
\cline { 2 - 5 } & \multicolumn{4}{|c|}{$\%$} \\
\hline Alnus & 7.5 & 9.9 & 12.6 & 6.2 \\
\hline Corylus & 3.9 & 4.1 & 3.5 & 1.0 \\
\hline Betula & 15.7 & 11.5 & 33.3 & 45.9 \\
\hline Populus & 7.9 & 18.5 & 3.4 & 10.2 \\
\hline Fraxinus & 16.6 & 8.0 & 5.9 & 9.5 \\
\hline Quercus & 8.0 & 4.5 & 7.8 & 0.6 \\
\hline Salix & 6.9 & 6.0 & 4.4 & 1.6 \\
\hline Pinaceae & 13.0 & 15.7 & 16.6 & 8.9 \\
\hline
\end{tabular}


Table 2

Pollen season parameters. SPI - Seasonal Pollen Index, MPA - Maximum Daily Pollen Appearance; KR - Kraków; PM - Piotrkowice Małe; GB - Giebułtów.

\begin{tabular}{|c|c|c|c|c|c|c|c|c|}
\hline \multirow[b]{2}{*}{ Season 2002} & \multicolumn{2}{|c|}{ SPI } & \multicolumn{2}{|c|}{ Start date ${ }^{1}$} & \multicolumn{2}{|c|}{$\begin{array}{c}\text { Duration of } \\
\text { season (days) }\end{array}$} & \multicolumn{2}{|c|}{ Peak concentration / date } \\
\hline & KR & $\mathrm{PM}$ & KR & PM & KR & $\mathrm{PM}$ & KR & PM \\
\hline Alnus & 742 & 913 & 31 & 38 & 43 & 58 & $61 / 03.02$ & $115 / 17.02$ \\
\hline Corylus & 376 & 365 & 33 & 38 & 45 & 49 & $17 / 09,12.02$ & $33 / 06.03$ \\
\hline Betula & 1545 & 1045 & 88 & 90 & 31 & 30 & $119 / 18.04$ & $92 / 19.04$ \\
\hline Populus & 782 & 1687 & 71 & 69 & 34 & 38 & $75 / 14.03$ & $450 / 17.03$ \\
\hline Fraxinus & 1615 & 724 & 78 & 91 & 44 & 67 & $119 / 01.04$ & $56 / 15.04$ \\
\hline Quercus & 787 & 409 & 82 & 116 & 53 & 26 & $64 / 04.05$ & $65 / 05.05$ \\
\hline Salix & 684 & 544 & 71 & 67 & 53 & 59 & $39 / 11.04$ & $113 / 03.04$ \\
\hline Pinaceae & 1297 & 1399 & 122 & 123 & 23 & 36 & $158 / 04.05$ & $203 / 15.05$ \\
\hline Season 2006 & $\mathrm{KR}$ & GB & $\mathrm{KR}$ & GB & $\mathrm{KR}$ & GB & $\mathrm{KR}$ & GB \\
\hline Alnus & 1996 & 800 & 86 & 87 & 16 & 41 & $457 / 31.03$ & $234 / 31.03 .06$ \\
\hline Corylus & 560 & 130 & 86 & 83 & 19 & 25 & $98 / 31.03$ & $34 / 30.03 .06$ \\
\hline Betula & 5218 & 6027 & 110 & 111 & 28 & 20 & $863 / 23.04$ & $1432 / 24.04 .06$ \\
\hline Populus & 535 & 1336 & 98 & 104 & 17 & 14 & $55 / 19.04$ & $817 / 21.04 .06$ \\
\hline Fraxinus & 941 & 1244 & 111 & 113 & 15 & 17 & $126 / 23.04$ & $177 / 24.04$ \\
\hline Quercus & 1216 & 76 & 113 & 16 & 31 & 51 & $89 / 15.05$ & $10 / 15.05 .06$ \\
\hline Salix & 682 & 213 & 102 & 103 & 27 & 36 & $57 / 01.05$ & 44 / 04.05.06 \\
\hline Pinaceae & 2602 & 1153 & 131 & 132 & 30 & 26 & $368 / 21.05$ & $215 / 21.05$ \\
\hline
\end{tabular}

${ }^{1}$ The consecutive day from the $1^{\text {st }}$ of January.

\section{DISCUSSION}

The lowest pollen percentage was recorded for Corylus in Kraków and its neighbourhood (Tab. 1). The only species Corylus avellana L. occurs commonly, especially on the outskirts of the city on small scattered sites. The highest percentage and SPI value were noted for Betula pollen at all the sites. In 2006 these values were considerably higher than in 2002. In 2006 these values were higher for Giebultów than for Kraków. In Kraków and in the suburban area, Betula pendula Roth. dominates. Gottardini and Crist of olini (1997), performing a similar study in two cities in northern Italy, found a higher pollen concentration of Betula in the bigger city (Trento) where Betula was planted as an ornamental tree.

Our study shows that the SPI value depends on both place and pollen season (Tab. 2 and Fig. 2). Variability in the SPI value in the different sites is associated with plant physiology (alternative cycles of high and low concentrations) and meteorological parameters (S pieksma et al. 1995). E - - Ghazaly et al. (1993), performing observations of pollen concentrations in Stockholm and Huddinge (15 km away from Stockholm), found significant differences between pollen annual totals. The highest percentage and annual total were observed for Pinus in Huddinge, while for Betula and Quercus in Stockholm. E l-G h a z ly et al. (1993) and Rodriguez-Rajo et al. (2004) insist on the fact that pollen annual totals are different between close monitoring sites. However, this relationship could be disturbed because of unstable weather conditions.

Different start and end dates of pollen seasons depend rather on meteorological factors than on monitoring sites (Frei, 1998; Emberlin et al. 2002). Gottardini and Cristofolini (1997) did not observe significant differences between start dates and pollen season duration in two sites in Italy, whereas Kasprzyk (2003) noted clear differences in start 


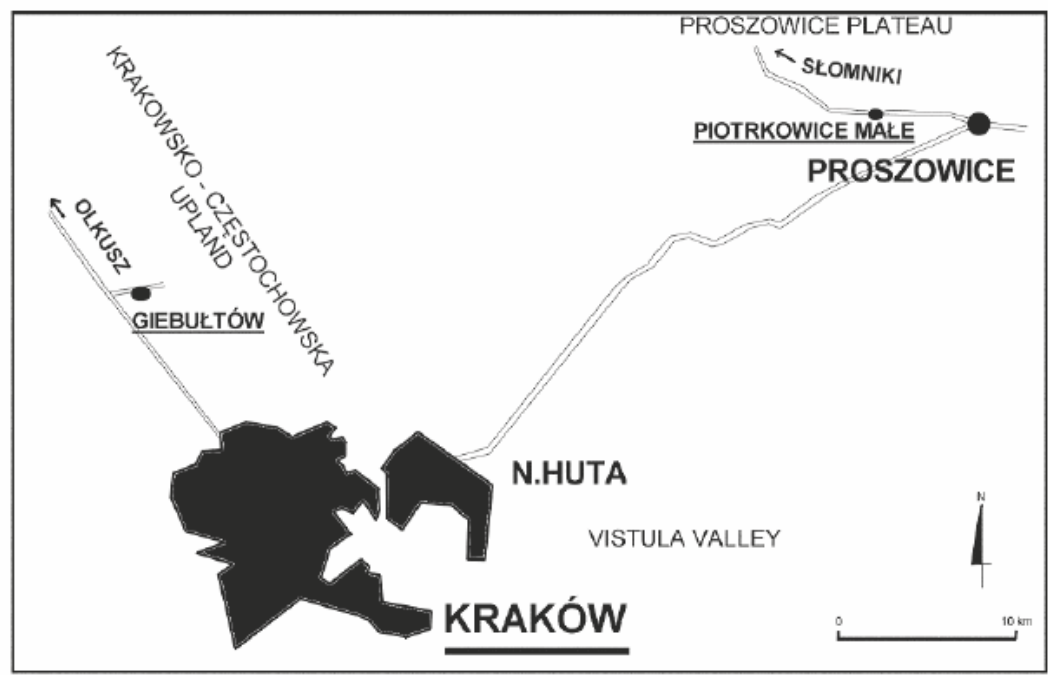

Fig. 1. Location of monitoring sites.
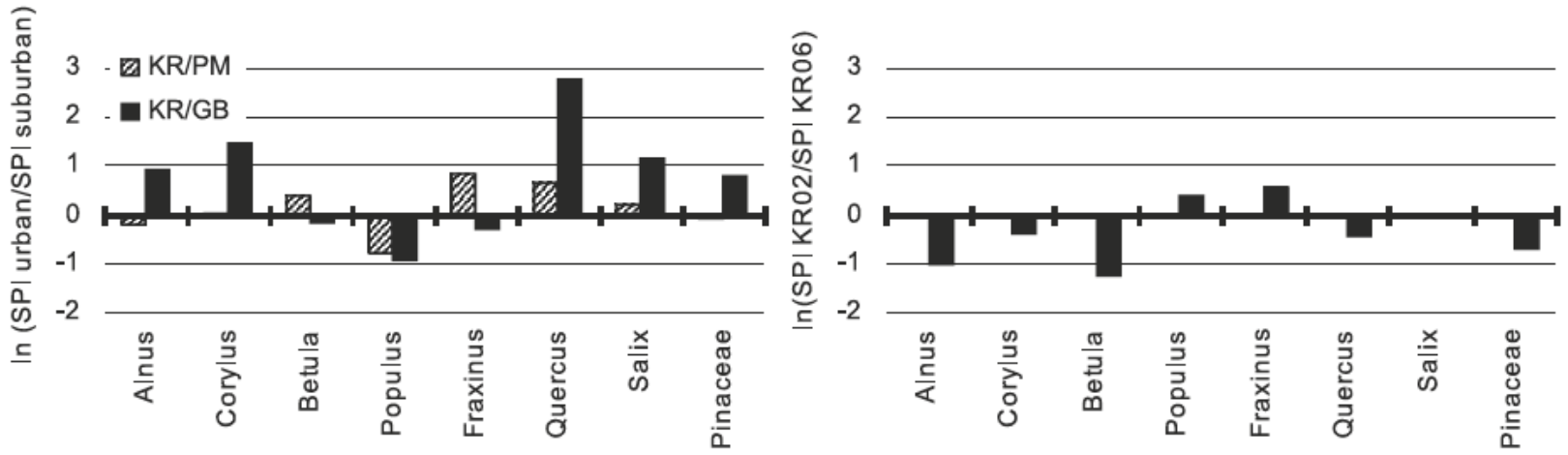

Fig. 2. SPI value ratio in the studied sites: Kraków vs PM/GB; Kraków 2002 vs Kraków 2006. All the logs of ratios depart significantly from 0 except at Corylus $\mathrm{KR}$ vs $\mathrm{PM} \mathrm{t}=0,40 ; \mathrm{p}=0.6863$, Pinaceae $\mathrm{KR}$ vs $\mathrm{PM} \mathrm{t}=1.96 ; \mathrm{p}=0.0496$ (borderline significant), Salix $\mathrm{KR}$ 02 vs $\mathrm{KR} 06 \mathrm{t}=0.05 ; \mathrm{p}=0.9569$.

dates of Alnus, Corylus, Betula in Rzeszów (Poland) in 1999-2001. Many authors reported a significant effect of air temperature on the beginning of the pollen season (Emberlin et al. 2002, Rodriguez-Rajo et al. 2004). In this study, the earlier occurrence of pollen of all the studied taxa was recorded in 2002, which was different from 2006, especially at the beginning of the year (Tab. 2).

It was found that several peak concentrations of pollen produced by one species of a tree or shrub could occur during one season and that the highest concentrations of all the taxa were noted earlier in 2002. The periods of low pollen concentration within the pollen season in 2002 (Corylus, Fraxinus) could be explained by unstable weather conditions (Fig. 3). Each of these taxa includes one species: Corylus avellana $\mathrm{L}$. and Fraxinus excelsior L. in the studied area. In 2002 the
Corylus pollen concentration decreased from 14 to 26 February. At that time, a decline in mean temperature was observed. The Fraxinus pollen season in Kraków in 2002 was marked by very quick achievement of a high concentration immediately after the start of the season and then by a clear decrease in the concentration. The concentration decrease coincided with the temperature decline below $0^{\circ} \mathrm{C}$ and rainfall. This tendency was not observed in PM where the pollen season started at the same time, although the initial part of the season was progressing very slowly. The similar multi-peak pattern for one species was observed by Rodriguez-Rajo et al. (2004) who indicated 7 peak concentrations for $\mathrm{Al}$ nus in Spain, although only Alnus glutinosa occurs in the north western part of Spain.

The occurrence of several pollen peak concentrations in one season for Salix and Populus is likely caused 

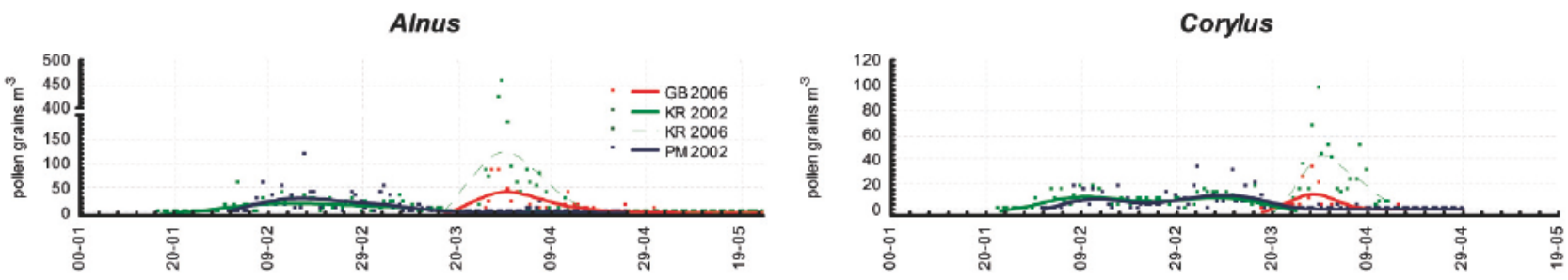

Populus
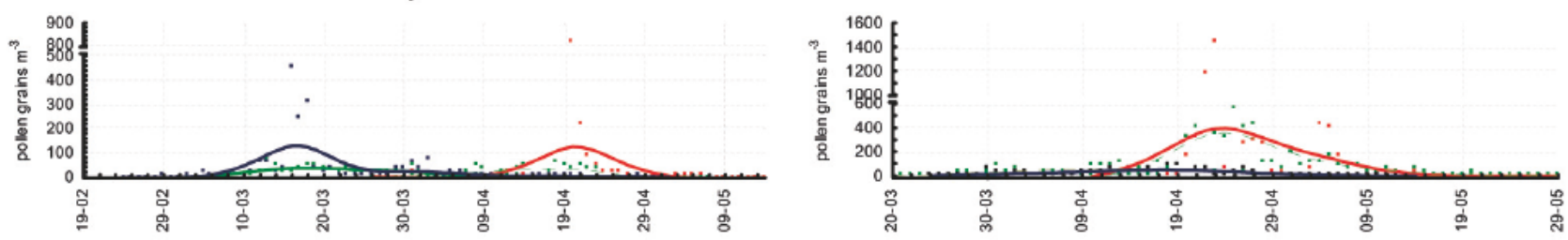

Pinaceae
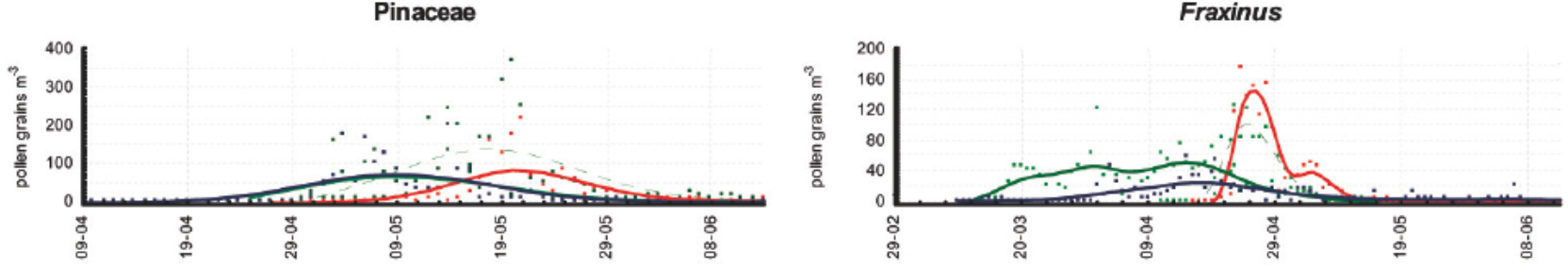

Salix
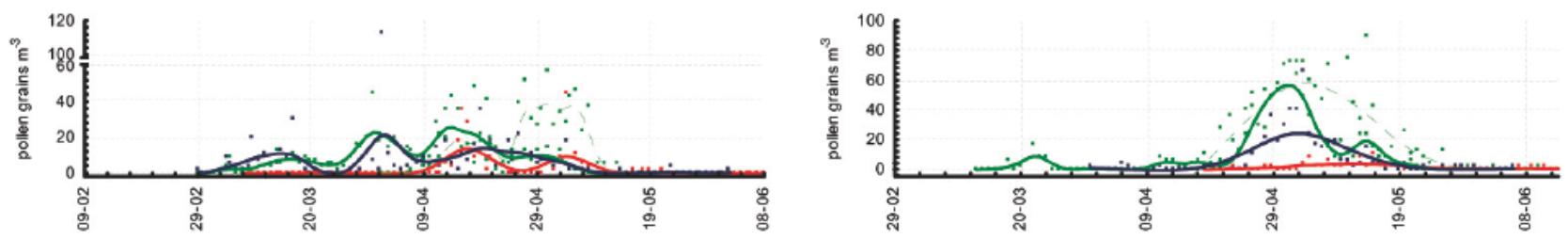

Fig. 3. Dynamics of pollen seasons. Single points present daily pollen concentrations, lines show the trends obtained using GAM model.

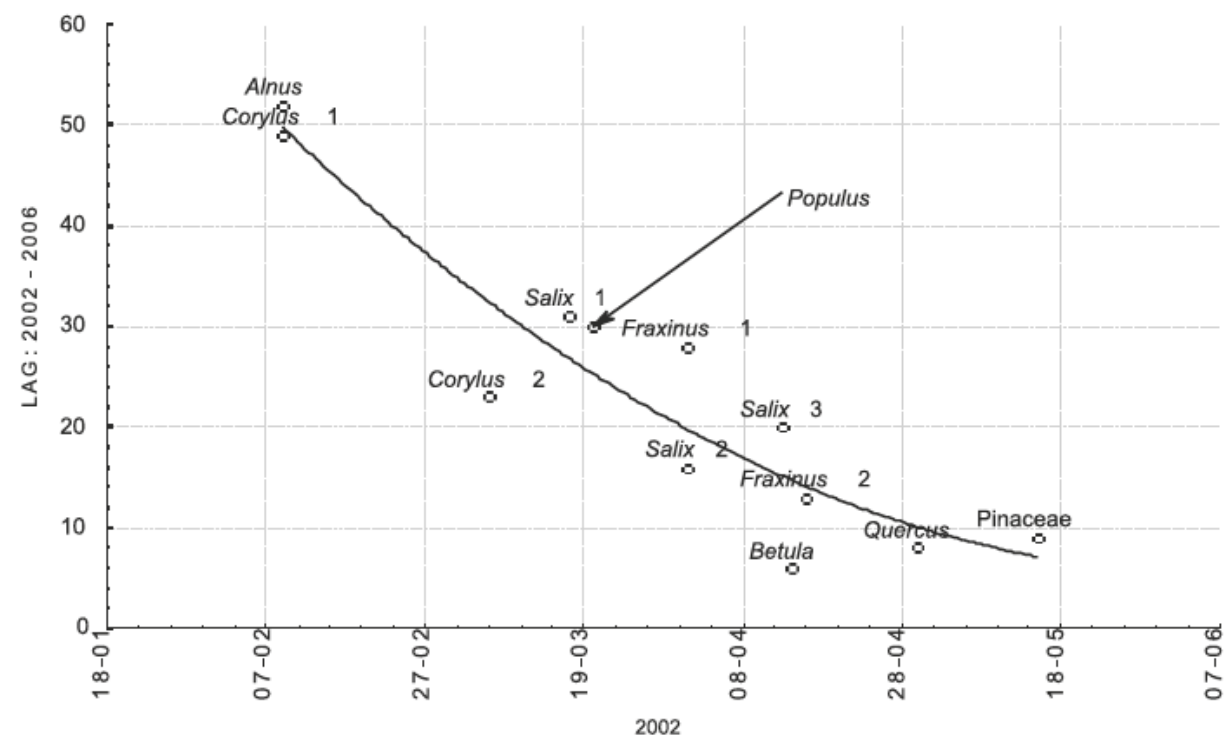

Fig. 4. The logs of maximum pollen concentrations between the daily pollen counts of selected taxa in 2002 and in 2006 (Kraków data). 


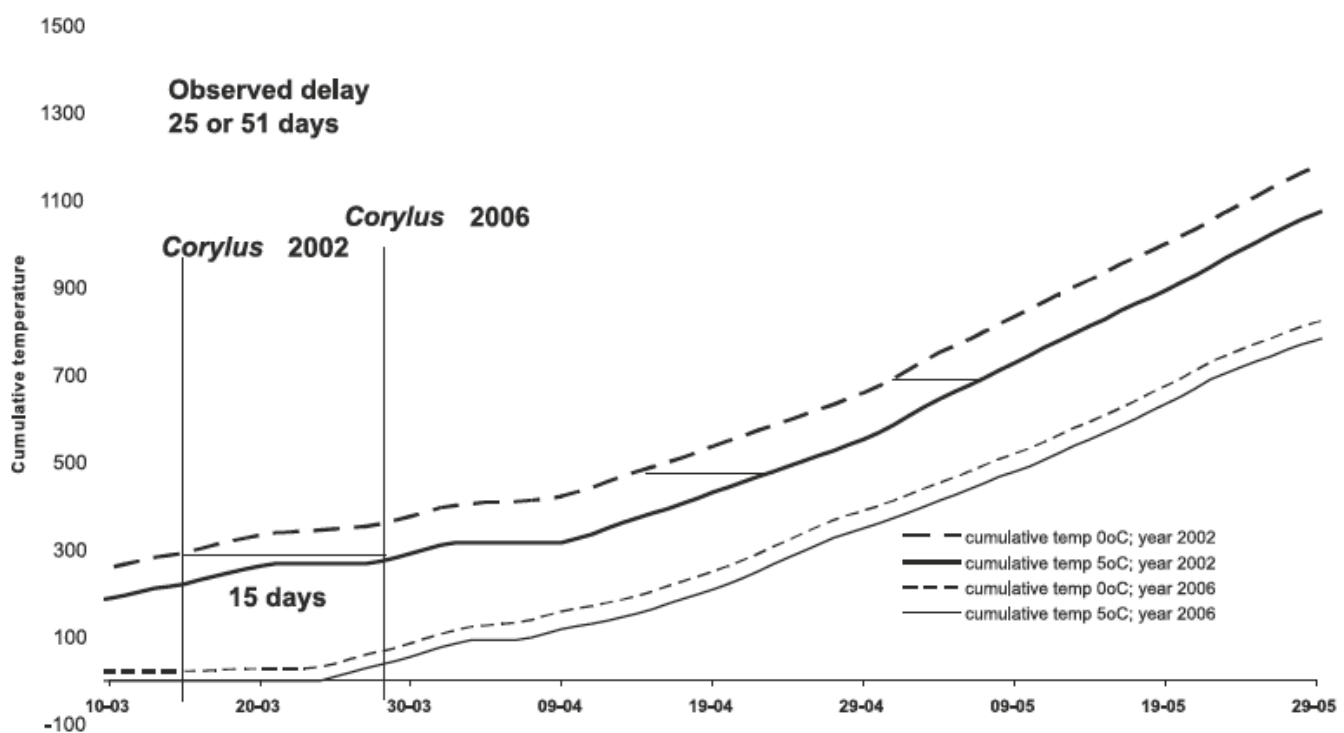

Fig. 5. Cumulative temperatures $>0$ and $5^{\circ} \mathrm{C}$ calculated from the $1^{\text {st }}$ January in 2002 and 2006.

by many species within these genera with various pollination periods. In Kraków and its vicinity, 13 species of Salix and 3 species of Populus were noted.

Many authors use cumulative temperature to predict the start of the pollen seasons and the highest concentrations. C lot (2001) applied cumulative temperature obtained by adding up mean daily positive temperatures from the $1^{\text {st }}$ of February to reach the value of $270^{\circ} \mathrm{C}$ for the estimation of the beginning of the season and the highest concentration of Betula pollen. He found a correlation between the peak concentration and high temperature. The results of our analysis showed that cumulative temperature $>5^{\circ} \mathrm{C}$ better explains later peak concentrations than cumulative temperature $>0^{\circ} \mathrm{C}$ (Fig. 5). However, the peak concentration delay which could be explained by this factor is qualitative. The spplication of cumulative temperature depends on a region where measurements are made. Min e ro et al. (1999) indicated a significant relationship between cumulative temperature over $2^{\circ} \mathrm{C}$ and $5^{\circ} \mathrm{C}$ and the start of the season for tree taxa occurring in Sevilla.

\section{CONCLUSIONS}

1. At all the studied sites, the lowest percentage of Corylus pollen and the highest percentage of Betula pollen were found.

2. The pollen seasons of all the analysed taxa started earlier in 2002.

3. Significant differences in the SPI value between the studied sites and between seasons were observed.

4. The dynamics of pollen seasons of some species showed more than one peak.

5 . The delay in maximum pollen concentrations is better explained by cumulative temperature $>5^{\circ} \mathrm{C}$ than $>0^{\circ} \mathrm{C}$.

\section{REFERENCES}

Clot B., 2001. Airborne birch pollen in Neuchâtel (Switzerland): onset, peak and daily patterns. Aerobiologia, 17: 25-29.

E1-Ghazaly G., E1-Ghazaly P. K., Larsson K. A., Nilsson S., 1993. Comparison of airborne pollen grains in Huddinge and Stockholm, Sweden. Aerobiologia, 9(1): 53-76.

Emberlin J., Detandt M., Gehrig R., Jäger S., Nolard N., Rantio-Lehtimaki A., 2002. Responses in the start of Betula (birch) pollen seasons to recent changes in spring temperature across Europe. Inter. J. Biomet. 46: 159-170.

Frei T., 1998. The effects of climate change in Switzerland 1969-1996 on airborne pollen quantities from hazel, birch and grass. Grana, 37: 172-179.

Fukuok a Y., 1997. Biometeorological studies on urban climate. Inter. J. Biomet. 40: 54-57.

Gottardini E., Crist ofolini F., 1997. Spring airborne pollen data in two sites in Trentino (Northern Italy): a comparison with meteorological data. Aerobiologia, 13: 199-204.

Hastie T., Tibshirani R., and Friedman J., 2001. The elements of Statistical Learning. Data Mining, Inference, and Prediction. Canada, Springer-Verlag.

Kasprzyk I., 1999. Comparative analysis of pollen fall at three sites in South-Eastern Poland. Ann. Agric. Environ. Med. 6: 73-79.

Kasprzyk I., 2003. Flowering phenology and airborne pollen grains of chosen tree taxa in Rzeszów (SE Poland). Aerobiologia, 19: 113-120.

L ew ińsk a J., 2000. Klimat miasta - zasoby, zagrożenie, kształtowanie. / The urban climate - potentials, threat, shaping. Instytut Gospodarki Przestrzennej i Komunalnej. Kraków.

Minero F. J. G., Morales J., Tomas C., Canda P., 1999. Relationship between air temperature and the start of 
pollen emission in some arboreal taxa in Southwestern Spain. Grana, 38: 306-310.

Rodriguez-Rajo F. J., Dopazo A., Jato V., 2004. Environmental factors affecting the start of pollen season and concentrations of airborne Alnus pollen in two localities of Galicia (NW Spain). Ann. Agric. Environ. Med. 11: 35-44.

Sokal R. R., Rhalf F. J.,1998. Biometry, the principles and practice of statistics in biological research. NY, USA, W. H. Freeman and Company.

Spieksma F.TH.M., Emberlin J., Hjelmroos M., Jäger S., Leuschner R. M., 1995. Atmospheric birch (Betula) pollen in Europe: Trends and fluctuations in annual quantities and the starting dates of the seasons. Grana, 34: 51-57.

Tow pas z K., 1996. Dolina Kluczwody. Soc. Polonica, 3. Kluczwody Valley.

Towpasz K., Kotańska M., Trzcińska-Tacik H., 1998. Notatki florystyczne z Płaskowyżu Proszowickiego (Wyżyna Małopolska). Fragm. Flor. Geobot. Ser. Polonica 5: 31-39. Floristic notes from Płaskowyż Proszowicki (Małopolska Upland).

Turzański K. P., Paula-Wilga J., 2002. Raport o stanie środowiska naturalnego miasta Krakowa za lata 1999-2001 z analizą porównawczą pięciolecia 1994-1998. / The report of the Cracow natural environment in the years 1999-2001 with regard to the comparative study in the period 1994-1998. 2002. Praca zbiorowa. Biblioteka Monitoringu Środowiska, Kraków.

\section{Sezony pyłkowe wybranych taksonów drzew i krzewów w Krakowie i okolicy}

\section{Streszczenie}

Celem badań było porównanie dynamiki sezonów pyłkowych wybranych taksonów drzew i krzewów w Krakowie oraz w okolicy Krakowa. Badania prowadzono w latach: 2002 (Kraków i Piotrkowice Małe) oraz 2006 (Kraków i Giebułtów). Zastosowano metodę wolumetryczną pobierania materiału i metodę 4 pasów horyzontalnych w liczeniu ziaren pyłku.

Najmniejszy udział procentowy zanotowano dla Corylus, natomiast największy dla Betula zarówno w mieście, jak i w okolicy. Różnice w datach początku sezonów pomiędzy punktami pomiarowymi były nieznaczne. Stwierdzono istotne różnice wartości SPI dla większości taksonów zarówno pomiędzy punktami pomiarowymi, jak i pomiędzy sezonami dla Krakowa.

Ocena przebiegu dynamik stężeń pyłku w sezonie wykazała istnienie: jednego, dominującego piku maksymalnych wartości (np. Betula, Pinaceae) lub występowanie wielu pików (np. Corylus, Populus, Fraxinus, Salix). Zaznaczanie się wielu pików tłumaczono występowaniem kilku gatunków danego taksonu na badanym terenie lub zmiennymi warunkami pogodowymi. W roku 2002 wartości maksymalne stężeń pojawiły się wcześniej niż w roku 2006. Różnice w datach maksymalnych stężeń pyłku tłumaczono efektywniej w sposób jakościowy $\mathrm{z}$ wykorzystaniem temperatury skumulowanej $>5^{\circ} \mathrm{C}$ niż $>0^{\circ} \mathrm{C}$. 
